Aletria, Belo Horizonte, v. 30, n. 4, p. 271-290, 2020

(c) (1)

\title{
A potência política de um feminino corpo-memória
}

\section{The Political Potential of a Feminine Memory-Body}

\author{
Elisa Amorim Vieira \\ Universidade Federal de Minas Gerais (UFMG), Belo Horizonte, Minas Gerais / Brasil \\ elisamorimvieira@gmail.com \\ http://orcid.org/0000-0002-8559-9547 \\ Camila Carvalho ${ }^{1}$ \\ Universidade Federal de Minas Gerais (UFMG), Belo Horizonte, Minas Gerais / Brasil \\ ccamilacarvalho45@gmail.com \\ http://orcid.org/0000-0001-5170-0283
}

Resumo: Tendo como guia um corpo-memória, que ao recuperar o passado a partir do não-dito revela sua latência no presente, em Jamás el fuego nunca (2007), de Diamela Eltit, literatura, política e História cruzam-se a todo tempo. Trata-se de uma narrativa na qual uma mulher sem nome rememora episódios passados ao mesmo tempo em que examina a banalidade do presente que compartilha com seu companheiro, o antigo líder de uma célula militante. Retomando a memória da ditadura chilena a partir daquele que talvez seja seu traço mais sinistro - o desaparecimento -, nesse romance, Eltit se aproxima da realidade histórica para acrescentar à discussão uma perspectiva irrealizável fora do horizonte da arte. Neste artigo, interessa-nos investigar em que medida a conversão desse rastro do passado em estratégia estética - ao colocar em disputa outras formas de visibilidade e inteligibilidade - dialoga com o conceito de História elaborado por Walter Benjamin.

Palavras-chave: Diamela Eltit; Walter Benjamin; Jamais o fogo nunca; ditadura; desaparecimento.

${ }^{1}$ Este trabalho contou com o apoio da FAPEMIG (Fundação de Amparo à Pesquisa do Estado de Minas Gerais).

eISSN: 2317-2096

DOI: $10.35699 / 2317-2096.2020 .20461$ 


\begin{abstract}
Guided by a body-memory, which in recovering the past from the unsaid reveals its latency in the present, in Jamás el fuego nunca (2007), by Diamela Eltit, literature, politics and History intersect at all times. It is a narrative in which an unnamed woman recalls past episodes while examining the banality of the present she shares with her mate, the degraded image of an authoritarian militant leadership. Resuming the memory of the Chilean dictatorship based on what is perhaps its most sinister feature - the disappearance -, in this novel, Eltit approaches historical reality to add to the discussion a perspective which is unrealizable outside the horizon of art. In this paper we are interested in investigating how the conversion of this trace of the past into an aesthetic strategy - when highlighting other ways of visibility and intelligibility dialogues with the concept of History elaborated by Walter Benjamin.
\end{abstract}

Keywords: Diamela Eltit; Walter Benjamin; Jamais o fogo nunca; dictatorship; disappearance.

Em 2003, num ensaio intitulado "La memoria pantalla", ${ }^{2}$ Diamela Eltit escreve sobre o modo como, naquele momento, os canais de televisão chilenos abordaram os trinta anos do golpe de Estado. Precipitam-se, ela diz. Numa competição tardia por mostrar imagens inéditas e exclusivas, as redes de televisão repetiam, incessantemente, o bombardeio que destruíra o Palacio de La Moneda. ${ }^{3}$ Em preto e branco, desfocada e evidenciando seu caráter de passado, a imagem de Salvador Allende explodia na tela. O protagonista era uma pessoa, jamais um projeto. Comprimidos, descontextualizados e oportunamente ordenados, os testemunhos proliferavam em tom de certificado. Com odioso equilíbrio, escreve Eltit (2008), concorriam na tela as palavras dos analistas, das vítimas e dos articuladores do golpe. De modo deliberadamente racional, no afã de estabelecer o episódio como um consenso, os canais rememoravam o passado amparados pela "sensatez que necessitam os tempos históricos para se cristalizar" (ELTIT, 2008, p. 102, tradução nossa) $;{ }^{4}$ e da mesma maneira em que colocaram em curso um silêncio exagerado, trinta anos mais tarde produziam uma superabundância de imagens. A rememoração postava-se como "um potente fármaco administrado em grandes doses

\footnotetext{
${ }^{2} \mathrm{O}$ ensaio integra a coletânea Signos Vitales, publicada em 2008.

${ }^{3} \mathrm{O}$ bombardeio, marco inicial da ditatura chilena, ocorreu em 11 de setembro de 1973 e fora comandado pelo general Augusto Pinochet.

${ }^{4}$ No original: "sensatez que necesitan los tiempos históricos para cristalizarse".
} 
para tranquilizar os ânimos, para acalmar as (más) consciências" (ELTIT, 2008, p. 103-104, tradução nossa). ${ }^{5}$ Com uma velocidade assustadora, os canais alternavam imagens do espetacular bombardeio, do presidente morto, do Estadio Nacional e do Estadio Chile. Não havia nesse suposto trabalho de memória a necessária revisão conceitual, como coloca Eltit, acerca da operacionalização destes campos de prisioneiros. Precisamente estes: Estadio Nacional e Estadio Chile. "Talvez fosse importante reparar na noção de estádio, nos nomes decisivos dos estádios, para assim pressagiar o prolongado assédio que alcançou a detenção" (ELTIT, 2008, p. 106, tradução nossa). ${ }^{6}$ Caberia questionar, ela escreve, como foi feita a gestão da ordem: a qual programa obedeciam? Que metodologia carcerária teve que se precipitar entre a clandestinidade e o céu aberto? (ELTIT, 2008). Embora se proliferassem obstinadamente, essas imagens não esclareciam o que era - e ainda é - necessário saber, porque a televisão oportunizava uma incursão turística ao passado.

É a crítica a uma determinada maneira de apreensão da História que Eltit deixa entrever nessa sua breve avaliação da memoria pantalla. Uma História pasteurizada, simplificada e polarizada. Uma História que não cessa de dividir seus personagens entre aqueles que apoiaram e aqueles que se opuseram bravamente ao absurdo que, embora tenha perdurado por dezessete anos, foi "finalmente superado". Uma História que ignora, a um só tempo, a gestação e o fruto. Uma História que recusa os pormenores, que coloca o passado em estado de repouso. Uma História incapaz de voltar-se àquele que talvez seja o ponto mais angustiante desse episódio sinistro: as vidas que desapareceram sem deixar rastros; a impressionante suspensão em que, ainda hoje, encontram-se os milhares de pessoas que, se já não se pode esperar que estejam vivas, tampouco podem ser dadas como mortas. Uma História que ignora essa suspensão fundamental. Uma História, enfim, que se volta ao passado para encerrálo e apagar sua latência no presente.

Essa máquina de desaparecimentos - à qual Pinochet deu forma - é, em seus diversos níveis, continuamente confrontada em Jamais $o$

\footnotetext{
${ }^{5}$ No original: "como un potente fármaco administrado en grandes dosis para tranquilizar los ánimos, para acallar las (malas) conciencias”.

${ }^{6}$ No original: “Quizás podría resultar importante reparar en la noción de estadio, en los nombres decisivos de los estadios, para así presagiar el prolongado asedio que alcanzó la detención”.
} 
fogo nunca. Tendo isso em vista, interessa-nos investigar, neste artigo, em que medida a conversão desse rastro do passado em estratégia estética - ao colocar em disputa outras formas de visibilidade e inteligibilidade - possibilita à literatura voltar-se à realidade histórica inserindo na discussão uma perspectiva irrealizável fora do horizonte da arte.

Em seu romance, Eltit nos apresenta uma narrativa em primeira pessoa na qual uma mulher sem nome rememora episódios passados ao mesmo tempo em que examina a banalidade do presente que compartilha com seu companheiro, o antigo líder de uma célula militante. O compromisso ideológico, que não permitia concessões, lhes custara a morte do único filho. Por viverem na clandestinidade, o casal não prestara socorro ao menino que, então, faleceu num quarto pequeno diante dos pais; o mesmo quarto onde, agora, a narradora realiza seu trabalho de memória e reflete sobre o que restou depois do fim da militância.

A tensão que subjaz à escolha da voz narrativa, esse corpo-ruína diletante, estende-se para o arranjo do romance como um todo: no lugar de um encadeamento de fatos, a autora insere a colagem de acontecimentos que não se relacionam de modo sequencial; em detrimento da pretensa totalidade de um enredo, volta-se para o interior rasurado e fragmentado da memória; negando violentamente as regras da cronologia, suspende o tempo até seu extremo. Aqui, o relato do que "de fato" ocorreu cede lugar à seleção "caoticamente cuidadosa" da narradora que, em detrimento dos "acontecimentos decisivos", privilegia a intensidade dos microeventos e o modo como a afetam.

A partir de dois corpos em ruína, o romance interpela o desaparecimento de um projeto político. Mas, a partir de dois corpos em ruína, traz à baila, também, as suas contradições internas que não cessam de ser apagadas. A partir de dois corpos em ruína, Eltit escova o passado a contrapelo para retirar do silenciamento a hierarquia de gênero que estruturou tanto o moralismo do Estado, quanto as organizações militantes. A partir de dois corpos em ruína, recoloca essa História local dentro de um quadro maior e mais amplo. Sem perder de vista as diversas camadas de violência nas quais se fundaram tanto o governo quanto a militância, Eltit recupera o imperativo econômico que, muito oportunamente, a História tende a relegar ao esquecimento: ao dar-se por satisfeita em expor a violação dos direitos humanos - sempre de modo seletivo, seriado e automático -, essa História parece tentar nos convencer de que é preciso separar o ato de sua motivação. Como se 
fosse possível. Feito brasa, fogo em latência, é um passado que não nega suas contradições que irrompe no presente, durante toda a narrativa.

Um romance, portanto, em constante estado de conflito, anunciado desde o título: uma dupla negação que Eltit toma emprestada de Los nueve monstruos, de César Vallejo. $\mathrm{O}$ verso do poeta peruano retorna, acompanhado de seu complemento, na epígrafe que abre o livro: "Jamais o fogo nunca/ fez melhor seu papel de morto frio". Nesse poema, Vallejo dialoga diretamente com a Guerra Civil Espanhola. A escolha de Eltit não é casual: como bem pontua Maria Rosa Oliveira-Williams (2009, p. 47, tradução nossa), são os versos de Vallejo que lhe dão "a chave poética para realizar o ato de escavação alegórica que torna possível o ressurgir dos revolucionários velhos à beira da morte ou já mortos". ${ }^{7}$ Se no título e na epígrafe do romance a relação entre a ditadura de Franco e aquela de Pinochet é tão somente insinuada, logo em suas primeiras páginas essa aproximação torna-se inconteste: "Não consigo lembrar quando Franco morreu" (ELTIT, 2017, p. 14). ${ }^{8}$ É desse modo aparentemente deslocado que a narradora inaugura sua incursão pela memória: "Quando foi, em que ano, em que mês, em que circunstâncias você me disse: Franco morreu, finalmente morreu" (ELTIT, 2017, p. 14, grifo nosso), ela continua.

A insistência em recordar o quando da morte do ditador espanhol - que orbita incessantemente os dois primeiros capítulos - não é um movimento fortuito. A morte de Franco é antes de tudo um símbolo. Não somente por tratar-se do óbito de alguém "que tinha exercido o direito soberano de vida e de morte [...] durante quarenta anos", como coloca Michel Foucault (1999, p. 296); mas, também, porque no período que antecedeu a expedição desse atestado, Franco permaneceu num estado de suspensão semelhante àquele em que se encontram os desaparecidos: nem vivo, nem morto.

Como se sabe, o general entrou em coma no dia 30 de outubro de 1975. Antes do coma, Franco teve três paradas cardíacas. Uma úlcera hemorrágica levou à retirada de boa parte de seu estômago. Peritonite bacteriana, insuficiência renal aguda, tromboflebite e pneumonia. Passou por inúmeras cirurgias e, durante um período, manteve-se vivo com a ajuda de aparelhos. Foi somente quase um mês depois do coma, no dia

\footnotetext{
${ }^{7}$ No original: "la clave poética para realizar el acto de excavación alegórica que haga posible el resurgir de los revolucionarios viejos al borde de la muerte o ya muertos". ${ }^{8}$ Para as citações de trechos do romance utilizamos a tradução feita por Julián Fuks para a edição brasileira da editora Relicário, de 2017.
} 
20 de novembro de 1975, que o general Franco morrera oficialmente. ${ }^{9}$ Oficialmente. Essa é uma palavra fundamental. Embora já não estivesse apto para viver, Franco só pôde ser considerado um homem morto quando seu óbito foi oficializado; quando seu corpo foi velado e enterrado. Ao fazer desse episódio seu ponto de partida, Diamela Eltit abre o romance com uma questão fundamental: quando se pode declarar que está morto um corpo?

Apesar de absolutamente negligenciada pela memoria pantalla, a lógica do desaparecimento é inseparável do período Pinochet. É Naomi Klein (2008) quem nos lembra que, ainda que o bombardeio em La Moneda tenha sido extremamente eficaz para instaurar o terror indispensável, vale lembrar, à implementação da agenda econômica dos Chicago Boys,$-{ }^{10}$ o espetáculo aéreo dos esquadrões de caça não tardara em converter-se num tipo desastroso de relações públicas:

\footnotetext{
${ }^{9}$ Esse breve apanhado acerca da saúde de Franco foi elaborado por Diana Klinger em seu artigo "A resistência: uma vida", publicado na revista ALEA em 2018, no qual a autora elabora uma leitura do romance de Eltit. A partir da morte de Franco, Klinger desenvolve uma reflexão acerca "da linha divisória entre a vida e a morte". Suas formulações caminham, contudo, numa direção diferente desta que ora propomos. O questionamento que guiará a reflexão de Klinger (2018, p.187) é de outra ordem: "Perguntar-se quando exatamente morreu Franco implicaria também se perguntar simultaneamente quando morre um corpo e quando morre um projeto político". Ainda que consideremos pertinentes as elaborações da autora, interessa-nos iluminar esse episódio, bem como sua inserção no romance, a partir de uma outra chave de leitura. Cf. Klinger (2018, p. 184-195).

${ }^{10}$ Em 1976, o economista e ex-embaixador de Salvador Allende em Washington, Orlando Letelier, depois de ter sido preso e torturado no Chile, retornou à capital norteamericana. Evidentemente, não mais como embaixador, mas "como ativista em um think tank progressista, o Institute for Policy Studies" (KLEIN, 2008, p.123). Letelier não hesitou em utilizar sua liberdade recentemente conquistada para denunciar as inúmeras violações que sofria o Chile sob o comando de Pinochet. Nesse mesmo ano, o economista escrevera um ensaio crítico para o Nation. Em seu A doutrina do choque, Naomi Klein (2008, p.124) reproduz um trecho desse texto: "O plano econômico teve de ser forçado e, no contexto chileno, aquilo só podia ser feito com a matança de milhares, com a implantação de campos de concentração em todo o país, com a prisão de mais de cem mil pessoas em três anos... Retrocesso para a maioria e 'liberdade econômica' para um pequeno grupo de privilegiados são, no Chile, as duas faces de uma mesma moeda". Menos de um mês depois da publicação desse ensaio, Letelier foi assassinado: no dia 21 de setembro de 1976, enquanto dirigia para o trabalho, uma bomba acionada por controle remoto explodira seu carro.
} 
Notícias da imprensa sobre os massacres realizados por Pinochet ganharam o mundo com estardalhaço, fazendo com que ativistas europeus e norte-americanos pressionassem seus governantes, com agressividade, para que não comerciassem com o Chile - um resultado significativamente desfavorável para um regime cuja razão de existir era manter o país aberto aos negócios. (KLEIN, 2008, p.109-110).

Pinochet vira-se, então, ante um dilema. Era preciso, a um só tempo, ampliar internamente a dimensão do horror e desviar-se dos ataques internacionais. A solução viria à galope, por meio da execução de uma nova prática: o desaparecimento. De modo silente, o Estado ampliava a zona de medo. Opositores simplesmente desapareciam. Seus corpos eram, por vezes, enterrados em valas comuns. Em outros casos, espalhavam-nos pelo deserto do Atacama. Houve, ainda, aqueles que foram lançados ao mar. Um método ainda mais eficaz: mães, pais, irmãs, filhos, filhas, esposas, maridos, amigos. Sara de Lourdes Donoso Palacios; Eliana Marina Espinoza Fernández; María Galindo Ramírez; Nalvia Rosa Mena Alvarado; Luis Emilio Recabarren González; Michelle Peña Herreros; José Luis Morales Ruiz; Elizabeth Mercedes Rekas Urra e outras 1084 pessoas. ${ }^{11}$ Todas, e cada uma delas, existindo em suspensão. Nem vivas, nem mortas. Por meio da ocultação ostensiva de seus rastros, ${ }^{12}$ Pinochet instaurava um luto que não tinha sequer materialidade. Como ignorar esse passado? Como lidar com ele? Como retirá-lo da condição

${ }^{11}$ As pessoas aqui citadas tiveram seus nomes retirados da lista de desaparecidos disponível no site oficial do Museo de la Memoria y Los Derechos Humanos. Disponível em: http://interactivos.museodelamemoria.cl. Acesso em: 1 maio 2019.

${ }^{12}$ Optamos pela formulação paradoxal "ocultação ostensiva" no intuito de enfatizar dois pontos importantes: o primeiro se refere ao fato de que, embora Pinochet fizesse desaparecer os corpos, esse gesto era visível para cada familiar que sofreu a impossibilidade do convívio. A ocultação era, portanto, evidente. O segundo se refere ao relativo insucesso dessa empreitada. $O$ general não fora capaz de esconder todos os seus rastros. Vários corpos foram encontrados, anos depois. E mais: muitos daqueles que permanecem desaparecidos contam, ainda, com a obstinação da busca de seus familiares (sobre esse último comentário Cf. NOSTALGIA DE LA LUZ, 2010). É nesse sentido que consideramos essa ocultação ostensiva um relativo insucesso: a cada dia que uma mãe se levanta e caminha pelo deserto; a cada vez que a literatura, o cinema ou as artes recuperam essas vidas, Pinochet experimenta, simbolicamente, o fracasso dessa sua empreitada que visava repousar num silêncio infinito cada um desses corpos. 
de mercadoria e convertê-lo num ato político? Como sopesar o excesso de memória e o exercício crítico da História, ainda absolutamente necessário?

É Walter Benjamin quem nos diz que uma leitura histórica efetiva - aquela que, para ele, seria elaborada pelo materialista histórico $-{ }^{13}$ não pode se furtar de dois gestos essenciais: a rememoração e a redenção. Ou, para recuperar a formulação de Michel Löwy (2005, p. 49), "a redenção sobretudo enquanto rememoração histórica das vítimas do passado". A Benjamin não interessa uma História que apenas conserve: no horizonte de seu pensamento, o diálogo entre passado e presente é inegociável. No conjunto das Teses que compõem o célebre "Sobre o conceito de História", talvez seja a Tese V aquela que expõe a questão de modo mais exemplar: "a verdadeira imagem do passado passa célere e furtiva" (BENJAMIN apud LÖWY, 2005, p. 62), ${ }^{14}$ ele escreve. Para além da evidente negação de uma noção cristalizada do passado, o que se esconde detrás dessa fugacidade é a relação dialética que ele estabelece com o presente. Trata-se, antes, de reconhecer essa imagem do que já foi no instante em que ela forma uma constelação com o que ainda é: no instante em que, como um relâmpago, ela passa. Um instante de perigo, nos dirá o filósofo na Tese seguinte. Se no quando da escrita desse documento o perigo iminente ao qual Benjamin faz referência era, sem

${ }^{13}$ É necessário frisar que o conceito de materialismo histórico no âmbito da filosofia de Benjamin não pode ser entendido tal qual aquele elaborado pela teoria marxista, em que pese o incontestável diálogo que a proposta do filósofo estabelece com essa última. Do ponto de vista benjaminiano, o termo guarda certas especificidades dialogando, inclusive, com a teologia - o que o distancia da formulação proposta por Marx. Em função das limitações deste artigo, não nos debruçaremos sobre essa diferença. Destacamos, contudo, que neste trabalho utilizamos o termo amparados pelo entendimento de Walter Benjamin. Sobre o tema cf. Löwy (2005) e Gagnebin (2018). ${ }^{14}$ Para a citação do texto de Benjamin, optamos por utilizar a tradução de Jeanne Marie Gagnebin e Marcos Lutz Müller elaborada para o livro de Michel Löwy, Walter Benjamin: aviso de incêndio: uma leitura das teses "Sobre o conceito de história". Nossa escolha se deve a duas questões: primeiro, em função dessa tradução ter sido feita a partir do original alemão (Über den Begriff der Geschichte); segundo, por ser aquela utilizada por Löwy e Gagnebin, autores aos quais recorremos para amparar nossa leitura das Teses. Assim, o uso do apud nessas citações não se deve a uma impossibilidade de consultar a fonte primária, publicada em português pela editora Brasiliense, mas à escolha consciente de não a utilizar. 
dúvida alguma, a ascensão do fascismo; esse não poderia ser, no nosso tempo, a aparentemente irrefreável mercantilização e espetacularização da memória? Que, em todo caso - é necessário indagar -, não parece estar, ainda, muito próxima desse - não tão - velho adversário?

No final da Tese VI, o filósofo escreve "que os mortos também não estarão seguros diante do inimigo, se ele for vitorioso" e que "esse inimigo não tem cessado de vencer" (BENJAMIN apud LÖWY, 2005, p. 65). Benjamin considera ser essa leitura equivocada da História contra a qual se volta - o que possibilita ao opressor continuar vencendo incessantemente. É, portanto, uma determinada forma de lidar com o passado que coloca os mortos em constante estado de ameaça, já que uma abordagem que opta por considerá-lo uma sucessão de êxitos não pode prescindir de falsificar e/ou ignorar os combates dos quais derivaram os vencedores e os vencidos. É urgente que a escrita da História não se furte a inverter a perspectiva: antes de configurar-se como uma "acumulação gradual de conquistas", o passado é "uma série interminável de derrotas catastróficas" (LÖWY, 2005, p. 66).

São, portanto, inseparáveis, no horizonte do pensamento de Benjamin, "história e política, rememoração e redenção" (LÖWY, 2005, p. 62). Escovar a História a contrapelo é, antes e sobretudo, restaurar o passado instaurando um dissenso: é negar-se a assentir com a versão dos vencedores; é exumar os mortos de seus túmulos para expor aquilo que se esconde por debaixo do consenso que organiza a "versão oficial". A rememoração, nos dirá Benjamin, só é efetiva quando trabalha a favor da redenção; quando se empenha em reconfigurar o tempo-do-agora expondo sua essência de barbárie. Rememoração do passado, redenção do presente. Jamais a separação. Jamais a inevitável progressão: tudo o que foi, poderia não ter sido; mas tudo o que agora é, resulta dessa contingência. Jamais a negação dessa contingência. ${ }^{15}$ " [...] Se trata de uma ação política, de uma reformulação produtiva, de gerar, eu lhe disse,

\footnotetext{
${ }^{15}$ A esse respeito, escreve Jeanne Marie Gagnebin: “[...] a verdade do passado reside antes no leque dos possíveis que ele encerra, tenham eles se realizado ou não. A tarefa da crítica materialista será justamente revelar esses possíveis esquecidos, mostrar que o passado comportava outros futuros além deste que realmente ocorreu. Trata-se, para Benjamin, de resgatar do esquecimento aquilo que teria podido fazer de nossa história outra história. A empresa crítica converge, assim, para a questão da memória e do esquecimento, na luta para tirar do silêncio um passado que a história oficial não conta". (GAGNEBIN, 2018, p. 60).
} 
um cenário atualizado, de voltar a ler, de pensar, se trata, eu disse, de tomar uma decisão, de intervir nos tempos" (ELTIT, 2017, p. 105). No prefácio do primeiro volume da edição brasileira das Obras escolhidas, Jeanne Marie Gagnebin (2012) sintetiza de maneira muito clara essa reconfiguração mútua na qual funda-se a leitura benjaminiana da História. Neste seu "Walter Benjamin ou a história aberta", a autora comenta que a preocupação do filósofo em salvar o passado no presente deve-se

[...] à percepção de uma semelhança que os transforma a ambos: transforma o passado porque este assume uma forma nova, que poderia ter desaparecido no esquecimento; transforma o presente porque este se revela como sendo a realização possível dessa promessa anterior, que poderia ter-se perdido para sempre, que ainda pode se perder se não a descobrirmos, inscrita nas linhas do atual. (GAGNEBIN, 2012, p.16).

Não seria justamente isso o que a memoria pantalla se nega a realizar? Embora não hesite em "acusar" o general Pinochet e ainda que não deixe de "criticar" a ditadura, esse suposto trabalho de memória, por mais que se esforce em esconder, acaba por expor a relação empática que estabelece com o vencedor quando opta por uma dupla negligência. A primeira refere-se à sua recusa em iluminar as engrenagens do mecanismo econômico que não só motivou o absurdo, como permanece, ainda, funcionando a todo vapor. ${ }^{16}$ A segunda tem a ver com o modo como esse trabalho de memória não hesita em selecionar os episódios dignos de rememoração, relegando ao esquecimento aqueles que, em alguma instância, poderiam criar um choque de interesses. É esse modus operandi - fundamentado por uma "identificação afetiva" com o vencedor - que nos leva a considerar o excesso de memória mercantilizada como o "nosso" possível instante de perigo. É esse modus operandi que, como escreve Eltit, segmenta as vítimas - em função dos imaginários sociais e seus componentes de gênero, raça e classe - "em mortos de primeira e de segunda. Torturados de primeira e de segunda. Memória social

\footnotetext{
${ }^{16}$ A ditadura chilena é inseparável da implementação de uma agenda neoliberal absolutamente austera. Uma política econômica que, embora tenha sido iniciada por Pinochet e seus Chicago boys, não fora suspensa no período da redemocratização e permanece, ainda hoje, em voga.
} 
de primeira e de segunda" (ELTIT, 2008, p. 107, tradução nossa). ${ }^{17}$ Uma seleção perversa que permite a Pinochet continuar vencendo. Incessantemente.

Mas como recuperar vidas cuja ausência não se deve, exatamente, à morte? Como fazê-las existir em sua crucial inexistência? Para fazer desaparecer uma vida, para relegá-la a essa impressionante suspensão, é preciso fazer desaparecer um corpo. O corpo é o veículo recordatório da morte, a "superfície de inscrição dos acontecimentos" (FOUCAULT, 2017, p. 65). O desaparecimento de um corpo é a tentativa mais torpe de negar os fatos. Como, então, elaborar a irrupção destes corpos sem perder de vista o extravio que sofreram? Como torná-los presentes sem negligenciar essa ausência fundamental que os constitui? Estruturado por dois personagens situados e sitiados entre a vida e a morte, Jamais o fogo nunca é uma alegoria do desaparecimento.

Me viro e sou eu agora a que prefere estar de lado, o trabalho magno dos ossos. Então, você se mexe com sutileza me seguindo, como se fôssemos os protagonistas de uma longa dança horizontal, os escolhidos para a realização de um baile extraviado. (ELTIT, 2017, p. 95, grifo nosso).

A partir desse rastro, Eltit escava o passado para dele exumar corpos em ruína. Corpos-memória. Duplamente. Corpos-memória porque guardam em si as inscrições, mas também porque só existem nesse espaço imaterial. Corpos desaparecidos que se convertem, no ambiente da ficção, em palavra, ação e resistência: "[...] porque agora somos corpos palavras, corpos, sim, palavras" (ELTIT, 2017, p. 30-31). Um corpo de homem degradado. Um corpo de mulher dotado de uma lucidez ambígua. Um corpo-palavra feminino que reconhece ser essa paradoxal existência - a dela e a do companheiro - dependente de um trabalho arqueológico. Um trabalho que escava o passado para reescrever a História a partir de seus restos, de seus ossos que são rastros:

[...] me alegra que você ainda sinta dor nos ossos, que você os sinta e eles se façam presentes a cada dia ou a cada noite, a cada hora, em todos os minutos, porque você praticamente não levanta da cama, da minha cama, e entende, tem que entender, que você

\footnotetext{
${ }^{17}$ No original: "muertos de primera y de segunda. Torturados de primera y de segunda. Memoria social de primera y de segunda".
} 
só está vivo pelo poder dos seus ossos que alardeiam a dor, essa engrenagem tão consistente que temos e somos ossos, esqueleto puro, você não acha? (ELTIT, 2017, p.115, grifo nosso).

Confinados em um espaço asfixiante, que só parece ser possível fora do tempo e da História - um quarto pequeno, hermético, cujas janelas estão sempre fechadas, mais próximo de um túmulo que de uma habitação -, esses corpos em ruína, em fase de putrefação e primordialmente ósseo - como nos diz constantemente a narradora -, transitam entre a vida e a morte, suspensos no tempo. Em certos momentos, parecem já estar mortos; em outros, assemelham-se mais a ex-militantes que, a despeito do fato de a idade avançada os aproximar da morte, ainda estão vivos. Uma questão indecidível que nos leva a propor uma alternativa de leitura tão distante das interpretações que tomam esses personagens por "fantasmas", considerando-os, portanto, ex-militantes já mortos; ${ }^{18}$ quanto daquelas que, ao contrário, fixam-nos no campo da vida, tomando-os como idosos cujos delírios são entendidos como sonhos ou sintomas de esclerose e/ou loucura. ${ }^{19}$ Ainda que sejam leituras possíveis - e essa é uma das potências do romance - essas interpretações ofuscam o movimento fundamental que somente o trânsito entre a vida e a morte possibilitaria. Justamente por situar-se numa zona de indiscernibilidade; precisamente por não se decidir por uma ou outra alternativa, Jamais o fogo nunca nos parece mais próximo de uma alegoria do desaparecimento. O movimento é político: recusandose a compartilhar do silêncio daqueles que simplesmente ignoram esse gesto nefasto e, ao mesmo tempo, a afiliar-se aos que, com certa dose de resignação, colocam como equivalentes o desaparecimento e a morte, Eltit evoca a memória do passado por meio da instauração de um litígio: vivos $e$ mortos ou, ainda, nem vivos, nem mortos.

[...] quando eu retornar ao quarto, quando vir você na cama vai parecer, eu sei, uma cena imutável e já não será possível para mim entender onde está exatamente a linha que rege o tempo. Habitei,

${ }^{18}$ Essa é a interpretação de Sergio Rojas (2012); de Francine Masiello (2012); e de Agustín Pastén (2012), para citar alguns exemplos. As referências completas desses textos encontram-se na seção "Referências" deste artigo.

${ }^{19}$ Essa é a interpretação de José Antonio Riviera Soto (2009) e de Eugenia Brito Astrosa (2015), para citar alguns exemplos. As referências completas desses textos encontramse na seção "Referências" deste artigo. 
sim, no meio de um finíssimo transtorno perceptivo. De forma incrivel, muito pouco exprimível, sofri essa anulação do tempo. Num dia de outro século, de outros séculos, um tempo em que caminhava e caminhava, mas não era capaz de avançar. (ELTIT, 2017, p. 35, grifo nosso).

O pensamento estético de Diamela Eltit parte dessa suspensão para, por meio dela, redesenhar os "possíveis" subvertendo a lógica desse gesto perverso. A estratégia é primorosa porque incorpora e afronta os objetivos dessa forma paradoxal de detenção, esse encarceramento para fora da História. Quando relegou ao desaparecimento grande parte de seus opositores, Pinochet visava repousar cada um desses corpos num silêncio infinito. Ao recuperá-los, sem perder de vista seu extravio, Eltit converte esse aprisionamento em plena liberdade. A voz que fala no romance fora arrancada brutalmente do todo social e, por isso mesmo, torna-se suficientemente distante para avaliá-lo; justamente por ter sido relegada a esta absurda suspensão, torna-se capaz de transitar pelo tempo:

Acompanhamos com distância, e até com uma frieza ostensiva, o acontecer em que se organiza o sempre colapsado presente. Cada vez que lemos o jornal, nos poupamos dos comentários, deliberadamente não manifestamos estranhamentos nem menos estupor diante da desmesura dos títulos. Só intercambiamos sorrisos fugazes quando algum excesso beira o patético. Sorrimos e possivelmente até mexemos a cabeça para confirmar o grau que alcançou o escândalo. Conhecemos com perfeição a alienação grotesca dos títulos, como também o exercício de síntese que requer uma leitura profissionalizada, a sondagem aguda que precisa da notícia. Depois de tudo fomos analistas talvez por um tempo prolongado demais. Aprendemos a administrar cada uma das variáveis, não apenas sopesá-las, e sim estabelecer suas intrincadas relações. Analistas. Nos desvelamos, permanecemos absortos, decifrando. Atuamos cumprindo nosso labor de militantes. Os erros que podemos ter cometido no começo das nossas funções conseguimos corrigir graças à nossa paixão exaustiva. Analistas de títulos, de parágrafos, de seções cruzadas, de sincronismos e diferenças, de matizes, de suspenses, a insaciável repetição de uma notícia, a manipulação grosseira. À maneira de um quebra-cabeças ou de um mapa desarticulado, restabelecíamos o território. (ELTIT, 2017, p. 47-48, grifos nossos). 
É, portanto, a indeterminação constitutiva desse corpo feminino o artifício estético-político que abre espaço para uma leitura histórica efetiva, para um trabalho de memória consistente. É essa indeterminação que oportuniza tanto o desenho de um tempo aberto, completamente alheio à cronologia e à linearidade, quanto o movimento dialético que a narradora elabora. Um eco benjaminiano. Em suas Teses, o filósofo nos dirá, de diversas formas, que o passado é um amontoado único de derrotas; uma única catástrofe acumulada. No romance, a temporalidade - que transita entre cinquenta, quinhentos ou mil anos - parece corroborar com essa leitura. Ao reconhecer que sua derrota remonta há décadas, séculos e milênios, o que essa mulher nos diz é que os vencidos do passado - de muitos passados - se imiscuem. Seu amontoar ininterrupto os torna indiscerníveis. A derrota dessa ex-militante é, portanto, anterior a si mesma. Não pertence unicamente ao seu tempo. Reporta-se, antes, a décadas, séculos e milênios de exploração e barbárie. Por meio dessa suspensão temporal, de modo cifrado, a mulher evoca as derrotas históricas que antecederam e se amalgamaram à sua:

Cem anos já e, apesar de saber que tudo foi consumado num passado remoto, em outro século e, ainda mais, em outro milênio, mil anos na verdade, ali está o século recente inteiro ou os mil anos decrépitos, insidiosos, que riem com um gesto horrivel ostentando sua esteira de desgraças. (ELTIT, 2007, p.122, grifo nosso).

A indeterminação constitutiva do desaparecimento é, portanto, a chave poética que permite ao romance elaborar uma leitura histórica capaz de circunscrever-se ao seu contexto e tema imediatos e, ao mesmo tempo, de extrapolá-los. Para recuperar as palavras de Benjamin, o passado que essa rememoração visita não é uma "cadeia de eventos", mas "uma única catástrofe, que sem cessar amontoa escombros sobre escombros" (BENJAMIN apud LÖWY, 2005, p. 87).

Aberturas e contradições acompanharão o leitor durante toda a narrativa. Para além do tempo e do espaço, o caráter ambíguo desse corpo ofusca, também, a nitidez de seu relato. Muito mais que referirse à imprecisão inerente a todo trabalho de memória, o que o estado "plenamente caótico" das reflexões da narradora evoca é esse limiar em que ela se encontra: feito fumaça, fogo em suspensão, seu relato é algo que se situa entre a rememoração e o delírio: 
Ali estavam os líderes históricos, eu podia vê-los alinhados por todo o cenário não sugestivo demais. Me incomodou a feitura do cenário. Eu disse a eles depois, mencionei que era necessário gerar uma cenografia que estivesse de acordo com o prestígio da Internacional. Apontei isso de uma maneira que poderia ser considerada irresponsável. Foi simplesmente uma opinião ou um comentário tangencial. Mas você e parte do grupo dos que depois formaria a segunda célula responderam de um jeito enfático demais. Aristocratizante, me chamaram, ou burguesa, não sei, não tenho certeza, não consigo definir agora a palavra. Mas havia uma plataforma árida, os corpos dirigentes, a melodia, as mãos, o canto. A diretoria do partido formando uma fila deprimente em cima daquele cenário impossível, aglutinados, indiferenciados, parecendo simples militantes, nunca dirigentes, isso não, você em compensação brilhava no canto assim como brilhavam o gordo López e Ximena e talvez até eu brilhasse (o gordo López, do canto do quarto, agora nega com a cabeça toda essa cena, pálido, furioso, mas já não me importa, tão pálido está o gordo enquanto Ximena fala comigo, insiste no meu assassinato, deitada do meu lado, me sussurra isso ao ouvido, em segredo). (ELTIT, 2017, p.110, grifos nossos).

A nebulosidade que configura o desaparecimento é uma constante em Jamais o fogo nunca. Por meio dessa apropriação, Eltit coloca em cena - para recuperar o termo de Jacques Rancière - uma nova partilha do sensível (cf. RANCIÈRE, 2009): aquela na qual o corpo mais barbaramente silenciado é o mais apto para falar. Uma partilha do sensivel na qual a verdade histórica não repousa na verificação de um acontecimento tal como ele foi, mas na legitimidade da voz que o narra. Uma partilha do sensivel para a qual a nitidez do relato importa menos que sua necessária irrupção.

Nesse sentido, não é casual o fato de ser o sujeito histórico que elabora essa revisão, uma mulher. Muito além de retirar do silenciamento uma voz marginalizada, fazer do quem um substantivo feminino é incluir no debate questões que são, não raro, desprezadas. Em que pese o fato de as contradições internas da militância lhe serem tão constitutivas quanto a brava resistência, nas narrativas que abordam o tema da ditadura, a opção por deixar de mencioná-las não é pouco frequente. A hesitação, no entanto, é mais que compreensível. Quando se trata do embate entre duas forças absolutamente desproporcionais, a crítica pode, de fato, 
parecer condescendente com o escandaloso assédio institucional ou acabar sugerindo - ainda que não intencionalmente -, uma relação de falsa semelhança que é, no mínimo, arriscada. Mas, ser mulher é correr o risco. Desenhar também. E, nesse sentido, o desenho de uma feminina releitura histórica não pode se esquivar de certas "inconveniências". Aproximar-se da ditadura militar por meio do escrutínio da masculina militância é enxergar nos escombros do passado aquilo que está mais profundamente submerso. Uma acuidade que somente o olhar de um ser-mulher é capaz de abrigar. A escolha da voz narrativa é, portanto, política porque possibilita a instauração de um duplo litígio: Jamais o fogo nunca, além constituir-se como espaço de fala para a voz mais barbaramente silenciada, não se exime de perscrutar as diversas camadas que perfilam esse silenciamento.

É precisamente essa escolha que oportuniza o questionamento de cada uma de nossas equívocas naturalizações. Quando o relato vem de uma mulher, o opressor não é o mesmo. Ou, pelo menos, não é somente o mesmo. No relato de uma mulher ex-militante não há espaço para maniqueísmos simplistas. A opressão que nos assola - ontem e hoje não escolhe espectro político. Aconteceu, como nos diz a narradora, $a$ torto e a direito. Articulada sim, de modo institucional, pelo Estado. Mas, elaborada também no seio da militância:

Frentista, ${ }^{20}$ estalinista, assassina louca. Uma palavra atrás da outra, um conjunto de palavras elaboradas em uma equação implacável. Sílabas sonoras, perfeitas, que iam organizando uma cadeia harmônica a ressoar como uma recorrente ladainha. Mas algo nessa engrenagem singular me cativou ou me distraiu, e é possível que meu rosto tenha permanecido inclinado ou atento a essas palavras, pode ser, sim, que nada no meu rosto tenha acusado a ofensa. E não parece estranho que essa expressão precisa, a minha, tenha me outorgado uma distância impressionante. Penso agora, incerta, insegura, e queria lhe perguntar se por acaso, no meio do caos, minha expressão chegou a alcançar a mais insólita exoneração. Pode ser que eu tenha imaginado, pensado naquelas tardes, horas, dias incertos em que o temor diante de uma voz

${ }^{20}$ Julián Fuks, tradutor do romance para o português, esclarece em nota - a qual reproduzimos - o significado do termo: "Nome utilizado para referir membros e apoiadores do grupo armado chileno 'Frente Patriótica Manuel Rodríguez (FPMR)', que lutava contra a ditadura de Pinochet. (N. do T.).” (ELTIT, 2017, p. 27). 
rotunda, sim, rotunda, pudesse me interceptar para cravar em mim uma soma de palavras que podiam significar ou não e que, no entanto, eram capazes de destruir. Ou era eu que me preparava para aquele instante, eu mesma que repetia aquilo que iam dizer, que se adivinha a torto e a direito. (ELTIT, 2017, p. 27).

Ao longo de todo o romance, a narradora revisita a hierarquia de gênero que estruturou as células de resistência. No entanto, nessa cena que abre o terceiro capítulo, ela o faz de modo peculiar. Num primeiro momento, demonstra reconhecer a frequência dos abusos e das acusações que sofria quando diz que, naquela reunião, as palavras duras que lhe foram dispensadas ressoaram como uma recorrente ladainha. Não bastava discordar de sua inclinação para a ação direta. Aos seus companheiros não parecia possível estabelecer um debate respeitoso com uma mulher. Não podiam, portanto, prescindir de certos adjetivos. Assassina. Assassina louca. Em seguida, o reconhecimento da engrenagem singular - isto é, a maneira ardil como a opressão se desenhava dentro da célula -, que a distraiu do impacto que aquela coerção lhe causara, oportuniza, então, o desvelamento; a identificação ou o questionamento acerca de seu próprio erro: também ela naturalizou o assédio; também ela aceitava e, de certo modo, reproduzia - porque temia e silenciava-se diante das acusações a opressão que se repetia a torto e a direito. É, portanto, a hierarquia de gênero aquilo que denuncia o cruzamento constrangedor entre ditadura e resistência. E, não por acaso, é uma cama - porque insólita e destituída de desejo - o espaço-gatilho para um trabalho de memória que confronta, obstinadamente, a persistente dominação masculina:

Algumas vezes me acontece: olhar para você como se não o tivesse visto nunca. E me parece surpreendente porque seu rosto perde a monotonia e ressurge diante de mim com uma força imprevista. Um rosto que carece de antecedentes. Eu o olho e sei que você nota meu assombro. Me aterroriza que exista em você um rosto que lhe pertence. Me assusta seu nariz, a boca e a fenda imperturbável que sua mandíbula conserva. Me impressiona esse rosto, o seu, contra a parede. Noto que é sua mandíbula, seu nariz e o contorno inalienável da sua cabeça recortada contra a parede. Abre passagem na minha mente uma sensação de chacota ou de engano que me esgota ainda mais. Você sabe como eu chego cansada. Sempre. Tento distanciar a impaciência que me invade porque temo, sim, as minhas próprias reações. A ferocidade com 
a qual eu poderia tentar destruir a autonomia da sua cabeça. (ELTIT, 2017, p. 79, grifo nosso).

Seu tom está carregado de dor e de indolência, escreve Julián Fuks no prefácio do romance. Sua leitura coloca sempre lado a lado a contraditória lógica militante, a derrota política da resistência e a imagem desse homem alquebrado e decadente. É essa a História que ela reconta: as diversas formas de violência que os levaram ao fracasso, sintetizam-se, no presente, na imagem desse corpo de homem completamente fragilizado.

Recuperando a memória da ditadura a partir daquele que talvez seja seu traço mais nefasto, Jamais o fogo nunca elabora um tipo de aproximação ao passado possível apenas ao universo da fabulação. Somente o espaço da ficção é capaz de abrigar um corpo que já não está. Somente no espaço da ficção, um corpo pode, em sua máxima deformidade, tomar a forma de vários corpos. Nesse lugar, a temporalidade pode ser violentamente oblíqua e o trânsito entre vida e morte, incontestavelmente legítimo. Explorando diversas possibilidades estéticas, Eltit se aproxima da realidade histórica, torna visível a absurda suspensão que configura o desaparecimento e insere na discussão uma perspectiva irrealizável fora do horizonte da arte. Nesse sentido, arriscamos, a derrota política é inseparável, em Jamais o fogo nunca, de uma crise da masculinidade. Uma crise que o romance edifica; uma crise à qual a ficção dá forma. Ao se beneficiar das potencialidades do espaço do qual emerge, a releitura que o romance elabora é literariamente política: negando-se a compactuar com a configuração vigente, desenha, em oposição, uma outra "topografia possível" que se baseia, fundamentalmente, na exposição das contradições internas da estrutura militante. Descentralização de uma lógica falocêntrica, em todos os sentidos, em cada um de seus níveis simbólicos: é isso o que o romance não cessa de edificar.

Por meio desse corpo duplamente marginal - porque feminino e desaparecido - e de sua indeterminação - porque vivo $e$ morto - que inquieta e desconcerta, o romance desorganiza o fluxo da rememoração mecânica e irreflexiva à qual a memoria pantalla tanto se empenha em nos acostumar. Uma partilha do sensível que perturba, desordena e opera pelo dissenso. Uma partilha do sensível que só é possível no ambiente da ficção. Uma partilha do sensível, enfim, que ao expor a potência discursiva da letra, parece ressoar, ininterruptamente: em tempos de repetições seriadas do mesmo, a literatura só é capaz de fazer política quando não deixa de ser literatura. 


\section{Referências}

ASTROSA, Eugenia Brito. La ciudad como laberinto psicótico en El padre mío y Jamás el fuego nunca de Diamela Eltit. Revista Chilena de Literatura, Santiago, n. 89, p. 77-91, abr. 2015. DOI: http://doi. org/10.4067/S0718-22952015000100005.

ELTIT, Diamela. Jamais o fogo nunca. Tradução de Julián Fuks. Belo Horizonte: Relicário Edições, 2017.

ELTIT, Diamela. Jamás el fuego nunca. Santiago de Chile: Editorial Planeta Chilena, 2007.

ELTIT, Diamela. La memoria pantalla. In: ELTIT, Diamela. Signos vitales: escritos sobre literatura, arte y política. Santiago, Chile: Ediciones Universidad Diego Portales, 2008. p. 101-107.

FOUCAULT, Michel. Aula de 17 de março de 1976. In: . Em defesa da sociedade: curso no Collège de France (1975-1976). Tradução de Maria Ermantina Galvão. São Paulo: Martins Fontes, 1999. p. 285-315.

FOUCAULT, Michel. Nietzsche, a genealogia e a história. In:

Microfisica do poder. Organização e tradução de Roberto Machado. . Rio de Janeiro: Paz \& Terra, 2017. p. 55-86.

GAGNEBIN, Jeanne Marie. Walter Benjamin ou a história aberta. In: BENJAMIN, Walter. Magia e técnica, arte e política: ensaios sobre literatura e história da cultura. Tradução de Sérgio Paulo Rouanet. 8. ed. São Paulo: Brasiliense, 2012. p.7-19. (Obras Escolhidas, 1).

GAGNEBIN, Jeanne Marie. Walter Benjamin: os cacos da história. São Paulo: N-1 edições, 2018.

KLEIN, Naomi. A doutrina do choque: a ascensão do capitalismo de desastre. Tradução de Vania Cury. Rio de Janeiro: Nova Fronteira, 2008.

KLINGER, Diana. A resistência: uma vida. ALEA, Rio de Janeiro, v. 20, n. 2, p. 184-195, maio/ago. 2018. DOI: http://doi.org/10.1590/1517106x/2018202184195.

LÖWY, Michel. Walter Benjamin: aviso de incêndio: uma leitura das teses "Sobre o conceito de história". Tradução de Wanda Nogueira Caldeira Brant, [tradução das teses] Jeanne Marie Gagnebin e Marcos Lutz Müller. São Paulo: Boitempo, 2005. 
MASIELLO, Francine. Cuerpo y catástrofe. In: CORTEZ, Enrique E.; KIRKPATRICK, Gwen (ed.). Estar en el presente: literatura y nación desde el Bicentenario. Lima: Latinoamericana Editores y Centro de Estudios Literarios Antonio Cornejo Polar, 2012. p. 493-513.

NOSTALGIA de la luz. Direção e roteiro: Patricio Guzmán. Fotografia: Katell Djian. Música: Miranda \& Tobar. Locução: Patricio Guzmán. Coprodução: Atacama Productions (França), Blinker Filmproduktion e WDR (Alemanha), Cronomedia (Chile) e Televisão Espanhola TVE (Espanha), 2010, 1 DVD (89 minutos).

OLIVEIRA-WILLIAMS, María Rosa. La década de 70 en el cono sur: discursos nostálgicos que recuerdan la revolución y escriben la historia. Romance Quarterly, [S.l.], v. 57, n. 1, p. 43-62, 2009. DOI: http:// doi.org/10.1080/08831150903334093. Disponível em: http://www. tandfonline.com/doi/full/10.1080/08831150903334093. Acesso em: 1 abr. 2020.

PASTÉN, Agustín. Radiografía de un pueblo enfermo: la narrativa de Diamela Eltit. Contracorriente, Raleigh, NC, v. 10, n. 1, p. 88-123, fall 2012.

RANCIÈRE, Jacques. A partilha do sensível: estética e política. Tradução de Mônica Costa Netto. São Paulo: EXO experimental (org.): Editora 34, 2009.

ROJAS, Sergio. Cuerpos sin mañana: cuando la historia es sólo memoria. In: ROJAS, Sergio. Catástrofe y trascendencia en la narrativa de Diamela Eltit. Santiago de Chile: Sangría Editora, 2012. p. 185-205.

SOTO, José Antonio Riviera. La muerte del tempo utópico en Jamás el fuego nunca de Diamela Eltit. Acta Literaria, Concepción, Chile, n. 39, p. 125-130. II sem. 2009.

VALLEJO, César. Poemas humanos. Lima: Editora Perú Nuevo, 1959.

Recebido em: 6 de maio de 2020. Aprovado em: 22 de outubro de 2020. 